\title{
Cumacea of Greece: a preliminary checklist
}

\author{
Panayota Koulouri ${ }^{\ddagger}$, Vasilis Gerovasileiou $\ddagger$, Nicolas Bailly $\ddagger$ \\ ‡ Institute of Marine Biology, Biotechnology and Aquaculture, Hellenic Centre for Marine Research, Heraklion, Greece
}

Corresponding author: Panayota Koulouri (yol72@hcmr.gr)

Academic editor: Christos Arvanitidis

Received: 20 May 2016 | Accepted: 03 Jul 2016 | Published: 01 Nov 2016

Citation: Koulouri P, Gerovasileiou V, Bailly N (2016) Cumacea of Greece: a preliminary checklist. Biodiversity

Data Journal 4: e9287. https://doi.org/10.3897/BDJ.4.e9287

\section{Abstract}

\section{Background}

The first attempt to compile the checklist of Cumacea of Greece was made in the context of the "Greek Biodiversity Database" project (2005-2008) coordinated by the Aristotle University of Thessaloniki. Since then, only scattered information on new elements of the Greek cumacean fauna has been available. The objectives of the present study were to update and cross-check taxonomically all cumacean species records from Greek waters for inaccuracies and omissions according to the recent literature and current taxonomic status.

\section{New information}

The updated checklist of Cumacea of Greece, which was built within the framework of the LifeWatch Greece Research Infrastructure (ESFRI) project (2013-2015) coordinated by the Hellenic Centre for Marine Research, comprises 62 species, classified in 24 genera and 6 families. However, a few more records need further cross-checking with the current literature resources. 


\section{Keywords}

Cumacea, Greece, Aegean Sea, Sea of Crete, Ionian Sea, Eastern Mediterranean, checklist

\section{Introduction}

The most important contributions to the Greek records of the taxonomic group of Cumacea have been made by Reyss (1974) and Bacescu (1982). Later on, Stefanidou (1996), Madurell and Cartes (2003), Mühlenhardt-Siegel (2009), Coll et al. (2010) and Koulouri et al. (2013) have provided new species records and distribution data on the Greek cumaceans. Most cumaceans are hyperbenthic animals, i.e. they are swimming bottomdependent macrofaunal organisms, performing seasonal or diel vertical migrations into the water column (Brunel et al. 1978). According to Dauvin and Vallet (2006), the hyperbenthos constitutes one of the dominant faunal components of the so called benthic boundary layer (BBL). The BBL is defined as the layer of water adjacent to the seabed and can be extended from a few centimetres to tens of metres, depending, both temporally and spatially, on various physical and biogeochemical processes (Marshall and Merrett 1977). This dynamic zone is characterized by higher concentrations of particles and biomass than the water layer immediately above it. Hyperbenthic sledges are commonly used for sampling these macrofaunal organisms. However, most sledges do not sample the supernatant layer above the seabed in order to avoid contamination of the samples with sediment and therefore there are still technical difficulties in sampling within this particular habitat (Mees and Jones 1997, Eleftheriou 2013, Koulouri et al. 2013).

A first attempt to compile the checklist of Cumacea was made in the context of the "Greek Biodiversity Database" project (2005-2008) coordinated by the Aristotle University of Thessaloniki. The documented occurrence of these marine species in Greek waters was recorded in a database that was set up online in 2010. The reference of Koukouras (2010) was specially created by the World Register of Marine Species (WoRMS)/European Register of Marine Species (ERMS, now part of WoRMS), for the list of these marine species provided by the Greek Biodiversity Database during the European project PESI.

The aim of the present work was to update the checklist of Cumacea of Greek waters. For this purpose, older lists were updated according to the recent literature and current taxonomic status.

\section{Materials and methods}

The checklist of Cumacea of Greece (Suppl. material 1) was built in the context of the Life WatchGreece (LWG) Research Infrastructure (ESFRI) project, in which the Greek Taxon Information System (GTIS) was established, as an application that has gathered efforts to develop a complete checklist of species recorded from Greek waters (Bailly et al. 2016, this 
special collection). The general principles for elaborating the Preliminary Checklist are provided by Bailly et al. (2016). The checklist of Cumacea was constructed on the basis of the species records extracted from the dataset of WoRMS/ERMS for marine species. Then, all recent publications were reviewed and the species reported to date have been added to the list. The classification system followed in the present checklist is the one proposed by the Cumacea World Database (Watling 2005).

\section{Checklist of Cumacea known to occur in Greek waters}

\section{Order Cumacea}

Family Bodotriidae

Bathycuma brevirostre (Norman, 1879)

Bodotria arenosa Goodsir, 1843

Bodotria parvui Petrescu, 2008

Bodotria pulchella (Sars, 1878)

Bodotria scorpioides (Montagu, 1804)

Cumopsis goodsir (Van Beneden, 1861)

Cyclaspis longicaudata Sars, 1865

Eocuma ferox (Fischer, 1872)

Eocuma sarsii (Kossmann), 1880

Iphinoe douniae Ledoyer, 1965

Iphinoe elisae Băcescu, 1950

Iphinoe maeotica Sowinskyi, 1893

Iphinoe rhodaniensis Ledoyer, 1965 
Iphinoe serrata Norman, 1867

Iphinoe tenella Sars, 1878

Vaunthompsonia cristata Bate, 1858

Family Diastylidae

Diastylis cornuta (Boeck, 1864)

Diastylis doryphora Fage, 1940

Diastylis jonesi Reyss, 1972

Diastylis neapolitana Sars, 1879

Diastylis rugosa Sars, 1865

Diastyloides bacescoi Fage, 1940

Diastyloides bosphorica (Băcescu, 1982)

Diastyloides carpinei Bacescu, 1969

Diastyloides serratus (Sars G.O., 1865)

Ekleptostylis walkeri (Calman, 1907)

Leptostylis macrura Sars, 1870

Makrokylindrus aegaeus Reyss, 1974

Makrokylindrus longipes (Sars, 1871)

Makrokylindrus spiniventris Hansen, 1920

Vemakylindrus charcoti (Reyss, 1974)

Vemakylindrus doryphora (Fage, 1940) 
Family Lampropidae

Hemilamprops normani Bonnier, 1896

Platysympus typicus (Sars, 1870)

Family Leuconidae

Eudorella nana Sars, 1879

Eudorella truncatula (Bate, 1856)

Leucon affinis Fage, 1951

Leucon longirostris Sars, 1871

Leucon macrorhinus Fage, 1951

Leucon mediterraneus Sars, 1878

Leucon siphonatus Calman, 1905

Family Nannastacidae

Campylaspis alba Hansen, 1920

Campylaspis glabra Sars, 1878

Campylaspis horridoides Stephensen, 1915

Campylaspis legendrei Fage, 1951

Campylaspis macrophthalma Sars, 1878

Campylaspis rostrata Calman, 1905

Campylaspis sulcata Sars, 1870 
Campylaspis verrucosa Sars, 1866

Campylaspis vitrea Calman, 1906

Cumella limicola Sars, 1879

Cumella pygmaea G.0. Sars, 1865

Cumellopsis puritani Calman, 1906

Nannastacus longirostris G.0. Sars, 1879

Nannastacus turcicus Băcescu, 1982

Nannastacus unguiculatus (Bate, 1859)

Procampylaspis armata Bonnier, 1896

Procampylaspis bacescoi Reyss \& Soyer, 1966

Procampylaspis bonnieri Calman, 1906

Styloptocuma gracillimum (Calman, 1905)

Family Pseudocumatidae

Pseudocuma longicorne (Bate, 1858)

Pseudocuma simile G.0. Sars, 1900

\section{Discussion}

A total of 62 species, classified to 24 genera and 6 families, constitute the updated checklist of Cumacea of Greece. A number of issues aroused during the thorough examination of the checklist of Cumacea of Greece derived from the dataset of WoRMS/ ERMS for marine species (Koukouras 2010). According to Coll et al. (2010), only two records of Iphinoe trispinosa (Goodsir, 1843) from the Mediterranean Sea exist. However, according to the revision of the genus Iphinoe by Ledoyer (1965), there are two more records, one from the North Aegean Sea (Stefanidou 1996) and another from the Gulf of Tunis (Ayari and Afli 2003). Moreover, the presence of two cumacean species recorded by 
Mühlenhardt-Siegel (2009) as Campylaspis cf. paeneglabra Stebbing, 1912 and Leptostylis cf. bacescoi Reyss, 1972 in the Mediterranean Sea still remains doubtful and should be confirmed. Therefore, further research is needed for the verification of the presence of these three species in the Greek waters. It is also worth mentioning that 27 cumacean species have been reported from the Turkish territorial waters of the Aegean Sea (Katagan 1983, Katagan 1985), while recently the new species Bodotria parvui was described by Petrescu (2008) from the same area. Though several species reported from the Turkish coasts of the Aegean have not yet been found in Greek territorial waters, they are expected to be recorded as elements of the Greek fauna in the future.

\section{Acknowledgements}

This work was supported by the LifeWatchGreece infrastructure (MIS 384676), funded by the Greek Government under the General Secretariat of Research and Technology (GSRT), ESFRI Projects, National Strategic Reference Framework (NSRF).

\section{References}

- $\quad$ Ayari R, Afli A (2003) Bionomie benthique du petit golfe de Tunis. Bulletin de l'Institut National des Sciences et Technologies de la Mer de Salammbô, Tunisia 30: 79-90.

- Bacescu M (1982) Contributions à la connaissance des Cumacés de la mer de Marmara et d'Egée (Île Eubea). Travaux du Muséum National d'Histoire Naturelle "Grigore Antipa" 24: 45-54.

- $\quad$ Bailly N, Gerovasileiou V, Arvanitidis C, Legakis A (2016) Introduction to the Greek Taxon Information System (GTIS) in LifeWatchGreece: the construction of the Preliminary Checklists of species of Greece. Biodiversity Data Journal LifeWatchGreece: Research infrastructure (ESFRI) for biodiversity data and data observatories: in press.

- $\quad$ Brunel P, Besner M, Messier D, Poirier L, Granger D, Weinstein M (1978) Le traîneau Macer-GIROQ: appareil amélioré pour l'échantillonnage quantitatif de la petite faune nageuse au voisinage du fond. Internationale Revue der gesamten Hydrobiologie und Hydrographie 63: 815-829. https://doi.org/10.1002/iroh.19780630612

- Coll M, Piroddi C, Steenbeek J, Kaschner K, Lasram FBR, Aguzzi J, Ballesteros E, Bianchi CN, Corbera J, Dailianis T, Danovaro R, Estrada M, Froglia C, Galil B, Gasol J, Gertwagen R, Gil J, Guilhaumon F, Kesner-Reyes K, Kitsos M, Koukouras A, Lampadariou N, Laxamana E, López-Fé de la Cuadra C, Lotze H, Martin D, Mouillot D, Oro D, Raicevich S, Rius-Barile J, Saiz-Salinas JI, Vicente CS, Somot S, Templado J, Turon X, Vafidis D, Villanueva R, Voultsiadou E (2010) The Biodiversity of the Mediterranean Sea: Estimates, Patterns, and Threats. PLoS ONE 5 (8): e11842. https:// doi.org/10.1371/journal.pone.0011842

- Dauvin JC, Vallet C (2006) The near-bottom layer as an ecological boundary in marine ecosystems: diversity, taxonomic composition and community definitions. Hydrobiologia 555: 49-58. https://doi.org/10.1007/1-4020-4697-9 5 
- Eleftheriou A (2013) Methods for the study of marine benthos. 4th Edition. Oxford, UK, John Wiley \& Sons, Ltd, 496 pp. [ISBN 978-0-470-67086-6]

- Katagan T (1983) Recherches systématiques et écologiques sur les Cumacés (Peracarida, Crustacea) littoraux de la mer Egée de Turquie. Ege University Faculty of Science Journal, Series B 6: 9-18.

- Katagan T (1985) Mysidacés et Cumacés des côtes Egéennes de Turquie. Rapports et Procès-verbaux de la Commission internationale pour l'Exploration scientifique de la Mer Méditerranée 29: 287-288.

- Koukouras A (2010) Check-list of marine species from Greece. Aristotle University of Thessaloniki, Greece. Assembled in the framework of the EU FP7 PESI project. In WoRMS. http://www. marinespecies.org/aphia. php?p=sourcedetails\&id=142068

- Koulouri P, Dounas C, Eleftheriou A (2013) Hyperbenthic community structure over oligotrophic continental shelves and upper slopes: Crete (South Aegean Sea, NE Mediterranean). Estuarine, Coastal and Shelf Science 117: 188-198. https:// doi.org/10.1016/i.ecss.2012.11.015

- Ledoyer M (1965) Sur quelques espèces nouvelles d' Iphinoe (Crustacea Cumacea). Discussion et description comparative des espèces européennes déja connues. Recueil des Travaux de la Station Marine d'Endoume 39: 253-294.

- Madurell T, Cartes JE (2003) The suprabenthic peracarid fauna collected at bathyal depths in the Ionian Sea (eastern Mediterranean). Crustaceana 76: 611-624. https:// doi.org/10.1163/156854003322316245

- Marshall NB, Merrett NR (1977) The existence of a benthopelagic fauna in the deep sea. In: Angel M (Ed.) A Voyage of Discovery: George Deacon 70th Anniversary. Pergamon Press Ltd, Oxford, $712 \mathrm{pp}$.

- $\quad$ Mees J, Jones MB (1997) The Hyperbenthos. Oceanography and Marine Biology: An Annual Review 35: 221-255.

- Mühlenhardt-Siegel U (2009) Cumacea (Crustacea, Peracarida) in the deep Mediterranean, with the description of one new species. Zootaxa 2096: 413-432.

- Petrescu I (2008) Bodotria parvui n. sp. (Crustacea, Peracarida) from the Turkish waters of the Aegean Sea (Results of "Focida"-2006 Expedition). Travaux du Muséum National d'Histoire Naturelle "Grigore Antipa" L1: 327-334.

- Reyss D (1974) Cumacés Résultats Scientifiques De La Campagne "Polymède li" Du N.O. "Jean Charcot" En Mer lonienne Et En Mer Égée (Avril-Mai 1972). Crustaceana 27 (2): 216-222. https://doi.org/10.1163/156854074x00442

- Stefanidou D (1996) Study of the benthic amphipods, isopods, tanaids and cumaceans (Peracarida, Crustacea) of the continental shelf of the North Aegean Sea. Aristotle University of Thessaloniki, Greece, 544 pp. [In Greek].

- Watling L (2005) Cumacea world database. http://www.marinespecies.org/cumacea

\section{Supplementary material}

\section{Suppl. material 1: Checklist of Cumacea (Arthropoda: Malacostraca) of Greece}

Authors: Panayota Koulouri, Vasilis Gerovasileiou, Nicolas Bailly

Data type: Checklist

Filename: GTIS_Cumacea_Greece_Checklist.xls - Download file (307.00 kb) 